\title{
Transfer of Genes Coding for Apoproteins of Reaction Centre and Light-harvesting LH1 Complexes to Rhodobacter sphaeroides
}

\author{
By C. NEIL HUNTER ${ }^{1 *}$ AND GEOFFREY TURNER 2 \\ ${ }^{1}$ Department of Pure and Applied Biology, Imperial College, Prince Consort Road, \\ London SW7 2BB, UK \\ ${ }^{2}$ Department of Microbiology, Medical School, University of Bristol, Bristol BS8 1TD, UK
}

(Received 24 November 1987; revised 1 February 1988)

\begin{abstract}
Several methods of introducing mobilizable cloning vectors by conjugation into the photosynthetic bacterium Rhodobacter sphaeroides have been examined. The efficiency of transfer was sufficiently high to enable a bank of $R b$. sphaeroides genes in Escherichia coli to complement non-photosynthetic mutants of $R b$. sphaeroides, thus providing a generally applicable method of isolating $R b$. sphaeroides genes. With a mutant incapable of synthesizing reaction centres and light-harvesting $\mathrm{LH} 1$ complexes as a recipient, the transfer of puf genes encoding reaction centre and light-harvesting LH1 polypeptides was examined in some detail. The spectroscopic and electrophoretic properties of this mutant and the newly photosynthetic transconjugant strain were consistent with the efficient transfer and expression of puf genes.
\end{abstract}

\section{INTRODUCTION}

Rhodobacter sphaeroides is a facultatively photosynthetic bacterium which houses the photosynthetic apparatus in a system of intracytoplasmic membranes. The synthesis of pigmented membranes occurs in oxygen-limited cells grown chemoheterotrophically in the dark, but this can be repressed by elevation of the oxygen tension. The regulation of membrane synthesis by oxygen, and the modulation of levels of photosynthetic components by light intensity, have provided valuable experimental models for the study of membrane biogenesis in photosynthetic systems.

The photosynthetic apparatus of $R b$. sphaeroides consists of light-harvesting pigment-protein complexes which funnel energy to a photochemical reaction centre complex. These complexes are embedded in the intracytoplasmic membrane; the major light-harvesting complex is designated $\mathrm{B} 800-850$ or $\mathrm{LH} 2$ and is arranged peripherally around a core containing the $\mathrm{B} 875$ (LH1) complex and reaction centres (Vos et al., 1986). The relatively simple structure and arrangement of light-harvesting and reaction centre complexes within the intracytoplasmic membrane provide attractive models for higher plant photosynthesis, particularly in view of the homology between bacterial reaction centres and photosystem two of oxygen-evolving systems (Deisenhofer et al., 1985).

These valuable features of $R b$. sphaeroides could be exploited more fully if it were possible to clone genes essential for photosynthetic function by complementation of photosynthetically defective mutants. This would make use of the ability of this bacterium to grow chemoheterotrophically without the need for photosynthetic complexes. Some photosynthetically inactive mutants have been isolated, for example the reaction-centre-less mutant PM8 (Sistrom \& Clayton, 1964), and several workers have identified promising approaches for efficient gene transfer (Miller \& Kaplan, 1978; Zinchenko et al., 1984). In the related bacterium Rhodobacter capsulatus these possibilities already exist (Youvan et al., 1983; Taylor et al., 1983) although other aspects of such work rely on a gene-transfer agent specific for this bacterium (Yen et al., 1979). 
Table 1. Bacterial strains and plasmids

\begin{tabular}{|c|c|c|c|}
\hline Strain or plasmid & Relevant characteristics & Source* & Reference \\
\hline $\begin{array}{l}\text { E. coli } \\
\text { DH5 }\end{array}$ & $\begin{array}{l}\text { A derivative of DH } 1 \text { (which is } \mathrm{F}^{-} \text {rec } A \text { end } A \text { gyrA } \\
\text { thi- } I \text { hsdR supE) }\end{array}$ & V.S. & Hanahan (1985) \\
\hline Sm10 & $\begin{array}{l}\text { recA thi thr leu; RP4-2-Tc::Mu integrated into } \\
\text { the chromosome; } \operatorname{Tra}^{+} \mathrm{Km}^{\mathrm{R}}\end{array}$ & R.S. & Simon et al. (1983) \\
\hline $\begin{array}{l}\text { Rb. sphaeroides } \\
\text { NC1B } 8253 \\
\text { NF3 }\end{array}$ & $\begin{array}{l}\text { Wild-type } \\
\text { Psg- }^{-}\end{array}$ & $\begin{array}{l}\text { R.A.N. } \\
\text { This work }\end{array}$ & \\
\hline $\begin{array}{l}\text { Plasmids } \\
\text { RSF1010 } \\
\text { pNH2 }\end{array}$ & $\begin{array}{l}\text { IncQ; } \mathrm{Su}^{\mathrm{R}} \mathrm{Sm}^{\mathrm{R}} \\
\mathrm{Sm}^{\mathrm{R}} \mathrm{Tc}^{\mathrm{R}} \text { derivative of RSF } 1010 ; 8.05 \mathrm{~kb} \text { Eco RI- } \\
\text { AvaI fragment of RSF } 1010 \text { ligated to } 1.4 \mathrm{~kb} \\
\text { Eco RI-Aval fragment of pAT153 bearing gene } \\
\text { for } \mathrm{Tc}^{\mathrm{R}}\end{array}$ & $\begin{array}{l}\text { G. Turner } \\
\text { This work }\end{array}$ & \\
\hline $\begin{array}{l}\text { pSUP202 } \\
\text { pJW1 }\end{array}$ & $\begin{array}{l}\mathrm{Ap}^{\mathrm{R}} \mathrm{Tc}^{\mathrm{R}} \mathrm{Cm}^{\mathrm{R}} ; \mathrm{Mob}^{+} \mathrm{Tra}^{-} \text {; ColE1 replicon } \\
\mathrm{Ap}^{\mathrm{R}} ; 12 \cdot 2 \mathrm{~kb} \text { Bam HI fragment bearing } R b . \\
\text { sphaeroides puf genes cloned into pBR322 }\end{array}$ & $\begin{array}{l}\text { R.S. } \\
\text { J.C.W. }\end{array}$ & Simon et al. (1983) \\
\hline pSRC2 & $\begin{array}{l}\mathrm{Ap}^{\mathrm{R}} \mathrm{Cm}^{\mathrm{R}} ; 7.2 \mathrm{~kb} \text { BamHI-HindIII fragment of } \\
\text { pJW1 cloned into pSUP202 }\end{array}$ & This work & \\
\hline pNH21 & $\begin{array}{l}\mathrm{Sm}^{\mathrm{R}} \text {; puf genes borne on } 13 \mathrm{~kb} \text { TaqI fragment } \\
\text { cloned into ClaI site of pNH2 }\end{array}$ & This work & \\
\hline pNH213 & $\begin{array}{l}\mathrm{Sm}^{\mathrm{R}} \text {; puf genes borne on } 12 \cdot 2 \mathrm{~kb} \text { Bam } \mathrm{HI} \\
\text { fragment from pJW1 cloned into pNH } 2\end{array}$ & This work & \\
\hline $\begin{array}{l}\text { RP1 } \\
\text { pRK2073 }\end{array}$ & $\begin{array}{l}\text { IncP1; } \mathrm{Ap}^{\mathrm{R}} \mathrm{Tc}^{\mathrm{R}} \mathrm{Km}^{\mathrm{R}} \\
\mathrm{Sp}^{\mathrm{R}} ; \mathrm{Tra}^{+} \mathrm{Mob}^{+} ; \text {ColE1 replicon }\end{array}$ & $\begin{array}{l}\text { P.B. } \\
\text { M.J.D. }\end{array}$ & Leong et al. (1982) \\
\hline
\end{tabular}

The purpose of this work is to describe a highly efficient gene-mobilization system which facilitates the transfer of cloned $R b$. sphaeroides DNA from Escherichia coli to mutants of $R b$. sphaeroides lacking photochemical reaction centres. Newly photosynthetic recombinants have been isolated ; the reaction centre activity observed is consistent with the transfer and expression of puf genes for reaction centre synthesis. The general application of this mobilization system for cloning a variety of genes from $R b$. sphaeroides is discussed.

\section{METHODS}

Media and antibiotics. $E$. coli strains were grown in LB medium. Rb. sphaeroides strains were grown in M22 medium (Sistrom, 1977) supplemented with sodium succinate $\left(4.6 \mathrm{~g}^{-1}\right)$, sodium glutamate $\left(0.27 \mathrm{~g} \mathrm{l}^{-1}\right)$ and aspartic acid $\left(0.04 \mathrm{~g} \mathrm{l}^{-1}\right)$. This is designated $\mathrm{M} 22+$. Where indicated, $0.1 \%$ Casamino acids were used to supplement this medium.

Antibiotics were used at the following concentrations for E. coli $\left(\mu \mathrm{g} \mathrm{m}^{-1}\right)$ : kanamycin 30, neomycin 30 , tetracycline 10, streptomycin 25, ampicillin 50, spectinomycin 50, chloramphenicol 25 . For $R b$. sphaeroides the concentrations were: kanamycin 20, neomycin 20, streptomycin 50 .

Bacterial strains and plasmids. These are listed in Table 1.

Chemical mutagenesis; identification and isolation of mutants. Rb. sphaeroides was mutagenized with $N$-methyl- $N^{\prime}-$ nitro- $N$-nitrosoguanidine (NTG). Photosynthetically grown cells $(5 \mathrm{ml})$ were suspended in sterile $10 \mathrm{mM}$-Tris buffer, $\mathrm{pH} 7 \cdot 5$, and NTG was added $\left(40 \mu \mathrm{g} \mathrm{ml}^{-1}\right.$ final concn) for $30 \mathrm{~min}$ in the dark. The cells were then washed in more sterile buffer. Photosynthetically defective mutants were enriched using $1 \mathrm{mg}$ ampicillin ml-1 to kill photosynthetically competent cells, followed by a period of chemotrophic growth in the dark. This cycle was repeated four times.

Colonies were photographed using the technique of Youvan et al. (1983), in which an enhanced degree of fluorescence is emitted from cells with defects in the photosynthetic apparatus. Putative mutants were purified by successive restreaking and photography. 
Preparation of membranes. Wild-type and mutant strains of $R b$. sphaeroides were grown in M22 + supplemented with $0.1 \%$ Casamino acids. Cells were harvested, washed twice in $10 \mathrm{mM}$-Tris pH 7.5 containing 1 mM-EDTA, and disrupted by sonication. The broken cell extract was layered onto a sucrose step gradient $(15 \% / 40 \%$, w/w), and after centrifugation for $4 \mathrm{~h}$ at $100000 \mathrm{~g}$ membranes were recovered from the interface.

$S D S-P A G E$. This was done using the buffer system described by Laemmli (1970) and a $12-17 \%(w / v)$ gradient of acrylamide.

Spectroscopy. Room-temperature absorption spectra were obtained on a Perkin-Elmer 554 spectrophotometer. Fluorescence emission transients were detected on an apparatus constructed from a photodiode detector (Hansatech, UK) equipped with an RG 780 Schott filter and connected to a Datalab DL902 transient recorder. Reaction centres were assayed using a Perkin-Elmer 557 dual-wavelength double-beam spectrophotometer, with the wavelengths for detection set at 598 and $575 \mathrm{~nm}$. Spectroscopy at $4 \mathrm{~K}$ was performed on apparatus described by Kramer \& Amesz (1982).

Preparation and analysis of DNA and RNA. Total DNA was prepared from $R b$. sphaeroides using a lysozyme/sarkosyl lysis procedure, followed by centrifugation in $\mathrm{CsCl}$. Cells were treated with $1 \mathrm{mg}^{\circ}$ lysozyme $\mathrm{ml}^{-1}$ for $10 \mathrm{~min}$ at $37^{\circ} \mathrm{C}$, then with $1 \mathrm{mg}$ proteinase $\mathrm{K} \mathrm{ml}^{-1}$ at $55^{\circ} \mathrm{C}$ for at least $6 \mathrm{~h}$ in the presence of $2 \%(\mathrm{w} / \mathrm{v})$ sarkosyl. $\mathrm{CsCl}$ was added $\left(1 \mathrm{~g} \mathrm{ml}^{-1}\right)$ and then ethidium bromide $\left(100 \mu \mathrm{g} \mathrm{ml}^{-1}\right)$. Following centrifugation at $150000 \mathrm{~g}$ for $20 \mathrm{~h}$ the genomic DNA was removed and dialysed.

Total RNA was prepared from $R b$. sphaeroides cells which were first treated with the extraction buffer described by Zhu \& Kaplan (1985). The cells were lysed in boiling $0.5 \%$ SDS for $5 \mathrm{~min}$ and the lysate was treated with $20 \mathrm{mM}-$ $\mathrm{KCl}$ followed by centrifugation to remove DNA and protein. 2-Mercaptoethanol was added to the supernatant to $170 \mathrm{~mm}$, followed by $\mathrm{CsCl}$ to $0.5 \mathrm{~g} \mathrm{ml}^{-1}$. This mixture was layered onto a $2 \mathrm{ml}$ cushion of $5.7 \mathrm{M}-\mathrm{CsCl}, 10 \mathrm{mM}-\mathrm{Tr}$ is pH 8, $100 \mathrm{~mm}$-EDTA in a $10 \mathrm{ml}$ centrifuge tube. RNA pellets were recovered from the tube following centrifugation at $100000 \mathrm{~g}$ for $18 \mathrm{~h}$.

Northern and Southern blots were performed using formaldehyde denaturing gels as described in Maniatis et al. (1982), and probed as described by Thomas (1983).

Plasmids were prepared on small and large scales by resuspending cells in $25 \%$ sucrose, $50 \mathrm{~mm}$-Tris pH 8.0. After treatment with lysozyme ( $1.4 \mathrm{mg} \mathrm{ml}^{-1}$ final concn) at $37^{\circ} \mathrm{C}$ for $2 \mathrm{~min}$ (small scale) or $20 \mathrm{~min}$ (large scale) the cells were lysed with Triton X-100 (1\%, v/v, final concn). After addition of EDTA ( $40 \mathrm{~mm}$ final concn) the lysate was cleared by centrifugation at $100000 \mathrm{~g}$ for $30 \mathrm{~min}$. The supernatant was treated with phenol/ $\mathrm{CHCl}_{3}$, and precipitated with 2-propanol. Large-scale preparations were purified further by centrifugation in $\mathrm{CsCl}$.

Conjugative crosses. Donor and recipient cells were washed once in LB medium and mixed in the ratio 1:20 E. coli: $\boldsymbol{R} \boldsymbol{b}$. sphaeroides (1:1:20 for triparental matings), with the optical density of each suspension set at approximately $\mathrm{OD}_{680}=2$. A $50 \mu \mathrm{l}$ sample of mixed suspension was placed on a well-dried plate of LB agar and left for 4-8 h at $32{ }^{\circ} \mathrm{C}$. The mixture was harvested, washed once in M22+ medium and spread on M22+ plates supplemented with neomycin.

Preparation of the $R b$. sphaeroides gene bank. Rb. sphaeroides total DNA was partially digested with TaqI and a 5$10 \mathrm{~kb}$ size fraction obtained from centrifugation of the digest on a $1 \cdot 25-5 \mathrm{M} \mathrm{NaCl}$ gradient at $150000 \mathrm{~g}$ for $3 \mathrm{~h}$. This DNA was ligated into the ClaI site of pNH2. Approximately 8000 clones in $E$. coli DH5 were obtained, with average insert size $5.5 \mathrm{~kb}, f=0.999$ (Maniatis et al., 1982). Total plasmid DNA representing this bank was transformed into $E$. coli strain Sm10 for transfer to $R b$. sphaeroides.

\section{RESULTS}

\section{Conjugative transfer of streptomycin resistance to mutant NF3}

Fig. 1 shows a restriction map of plasmid $\mathrm{pNH} 2$, a vector based on the IncQ group plasmid RSF1010; the broad host range of RSF1010 and derivatives has been reviewed by Franklin (1985). The tetracycline-resistance gene was inserted to provide BamHI and ClaI sites within pNH2 for construction of gene banks from Sau3A or TaqI partial digests. The efficiency of transfer of pNH2 from $E$. coli to $R b$. sphaeroides was measured using the transfer functions of the IncP1 group plasmid RP4. These functions can be provided either triparentally, or by using $E$. coli strain Sm10 (see Table 1), in which RP4 is integrated within the E. coli chromosome and does not transfer to the recipient. In further triparental matings, pRK2073 was used to provide transfer functions; in this case this plasmid is mobilized but the ColE1 replicon does not function in $R b$. sphaeroides (Hunter, 1988).

The data in Table 2 show that the efficiency of transfer is very high, at best $5 \times 10^{-1}$ per recipient. Some of the triparental matings are less efficient, and are not suitable for transferring a gene bank to $R b$. sphaeroides mutants, but nevertheless are the preferred method for cloning and transfer of single fragments (see below). 


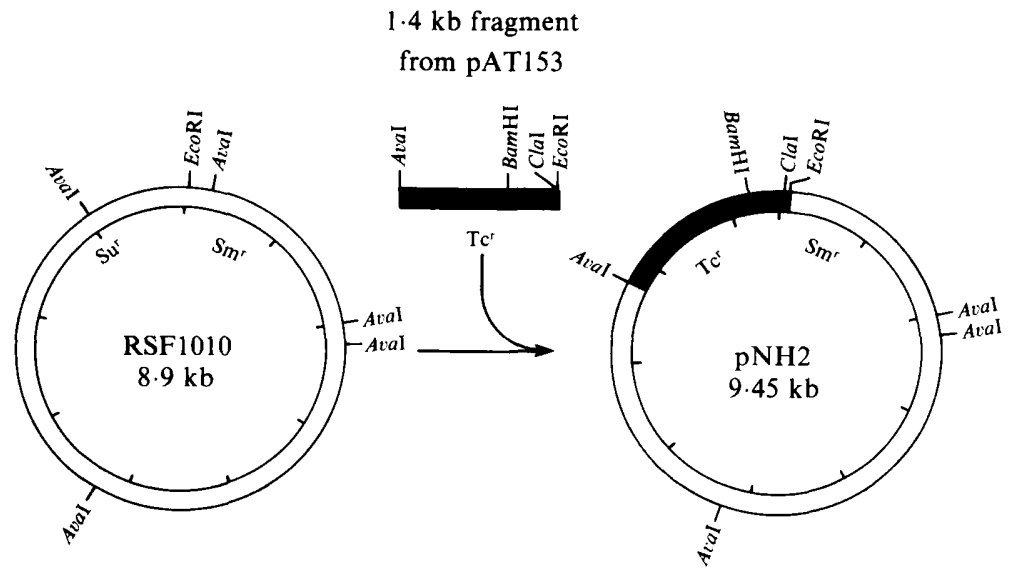

Fig. 1. Restriction map of cloning vector $\mathrm{pNH} 2$.

Table 2. Conjugative transfer of streptomycin resistance from $E$. coli to $R b$. sphaeroides mutant NF3

The transfer efficiency is quantified as the number per recipient. The average insert size for the gene bank was $5.5 \mathrm{~kb}$ (see Methods).

Donor strain

$\mathrm{Sm} 10(\mathrm{pNH} 2)$

DH5(pNH2) $\times$ DH5(RP1)

DH5(pNH2) $\times$ DH5(pRK2073)

$\mathrm{Sm} 10(\mathrm{pNH} 21)$

$\mathrm{Sm} 10(\mathrm{pNH} 2$ gene bank)
Efficiency

$5.6 \times 10^{-1}$

$1.9 \times 10^{-2}$

$1.6 \times 10^{-2}$

$8.1 \times 10^{-2}$

$1.4 \times 10^{-2}$

\section{Complementation of mutant NF3 using the Rb. sphaeroides gene bank}

The gene bank in E. coli Sm10 (see Methods) was mobilized into the photosynthetically inactive reaction-centre-less mutant NF3, and selection for photosynthetic ability and for streptomycin resistance was applied. The lack of reaction centre activity and the fluorescence properties of NF3 are shown in Figs 2-5. In a mating with $10^{8}$ recipient cells, a maximum of $1.4 \times 10^{6}$ streptomycin-resistant transconjugants would be expected, assuming a transfer frequency of $1.4 \times 10^{-2}$ per recipient (Table 2). Of these, 280 would also have regained the ability to photosynthesize if the puf operon (Zhu et al., 1986) is represented in the bank with a frequency of $2 \times 10^{-4}$. In practice, around 50 photosynthetic, streptomycin-resistant colonies were obtained.

\section{Isolation and characterization of pNH21}

Two possibilities were explored for obtaining the desired clone from the gene bank, once complementation of NF3 had been established. In the first, the gene bank was divided into ten pools and the pool which complemented NF3 was identified. The process was repeated with further subdivisions until the positive clone was found. Further tests were carried out which involved purification of this clone by streaking, isolation of the plasmid DNA and retesting of this DNA by transformation into $E$. coli followed by more matings. In the second approach, cleared lysates from the newly photosynthetic recombinant strain of $R b$. sphaeroides NF3 were prepared and transformed into $E$. coli, with selection for streptomycin resistance. Hybridization tests demonstrated that puf genes could be 'rescued' in this way, but with other genes success has been variable (C. N. Hunter, unpublished results). Accordingly, the first procedure is followed routinely, and has been used successfully to isolate genes important for the regulation of bacteriochlorophyll biosynthesis (Coomber et al., 1987; Hunter \& Coomber, 1988). 
(a)

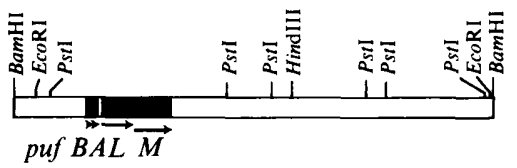

(b)

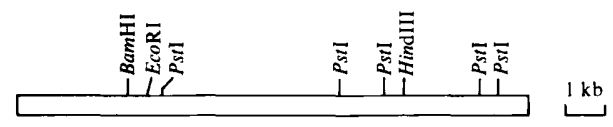

Fig. 2. A comparison of insert DNA from plasmids pJW1 and pNH21. (a) $12 \cdot 2 \mathrm{~kb}$ BamHI fragment from pJWl showing the location of puf genes and restriction sites for BamHI, EcoRI, PstI and HindIII. (b) $13 \mathrm{~kb}$ TaqI partial fragment of pNH21 from the $R b$. sphaeroides gene bank.

Table 3. Conjugative transfer of puf genes from $E$. coli to $R b$. sphaeroides mutant NF3

Efficiency quantified as for Table 2; gene bank as for Table 2.

\begin{tabular}{ll}
\multicolumn{1}{c}{ Donor strain } & Efficiency \\
Sm10(pNH2 gene bank) & $5.4 \times 10^{-7}$ \\
Sm10(pNH21) & $8.1 \times 10^{-5}$ \\
DH5(pNH21) $\times$ DH5(RP1) & $4.6 \times 10^{-6}$ \\
DH5(pNH21) $\times$ DH5(pRK2073) & $1.3 \times 10^{-5}$ \\
Sm10(pSRC2) & $1.4 \times 10^{-4}$ \\
DH5(pSRC2) $\times$ DH5(RP1) & $3.0 \times 10^{-5}$ \\
DH5(pSRC2) $\times$ DH5(pRK2073) & $5.0 \times 10^{-5}$
\end{tabular}

Further work on complementation of $R b$. sphaeroides mutants has employed the mobilizable 'suicide' vector pSUP202, which does not replicate in a variety of Gram-negative bacteria, including Rb. sphaeroides (Simon et al., 1983; Hunter, 1988). In this case, complementation by recombination necessarily occurs when photosynthetic selection is applied and therefore the plasmid cannot be rescued from cleared lysates in the manner described above. Thus the first method of identifying the clone containing the gene in question is used. The efficiency of transfer of puf genes cloned in pSUP202 is quantified in Table 3.

The map of the insert of pNH21 which restores photosynthetic growth to mutant NF3 is shown in Fig. 2(b). This insert is similar to that of the plasmid pJW1 which is included here for comparison, and which contains a $12.2 \mathrm{~kb}$ BamHI fragment cloned into pBR322 (Fig. 2a). This plasmid contains puf $A, B, L$ and $M$ genes, which encode $\alpha$ and $\beta$ subunits of the B875 antenna complex and the $\mathrm{L}$ and $\mathrm{M}$ subunits of the reaction centre, respectively (Williams et al., 1983, 1984). Mapping and hybridization data (not shown) confirm the presence of puf genes in pNH21 and imply that the function of puf $L$ or $M$ is disrupted in mutant NF3 (see also Fig. 6). Four other mutants, NF2, NF4, NF6 and NF9, were also complemented by pNH21.

\section{A comparison of different methods for conjugative transfer of puf genes}

In order to establish the relative merits of different methods of conjugative transfer to $R b$. sphaeroides mutants, a variety of mating crosses with mutant NF3 were performed (see Table 3 ). To allow a comparison of puf gene transfer using vectors based on either RSF1010 or pSUP202, pSRC2 was constructed; this plasmid contains the $7.2 \mathrm{~kb} \mathrm{BamHI-HindIII}$ fragment of pJW1 cloned into pSUP202. All six systems efficiently transferred puf genes to NF3, resulting in the production of photosynthetic transconjugants at a frequency of $10^{-4}$ to $10^{-6}$ per recipient. For pNH21, transfer of the streptomycin-resistance marker is at least two orders of magnitude more efficient than transfer of puf genes; therefore it appears that some factor other than transfer limits the function of the newly transferred puf genes. Recombination at the site of puf genes in NF3 would account for this, and appears to occur with a frequency of $10^{-3}$ to $10^{-4}$. 

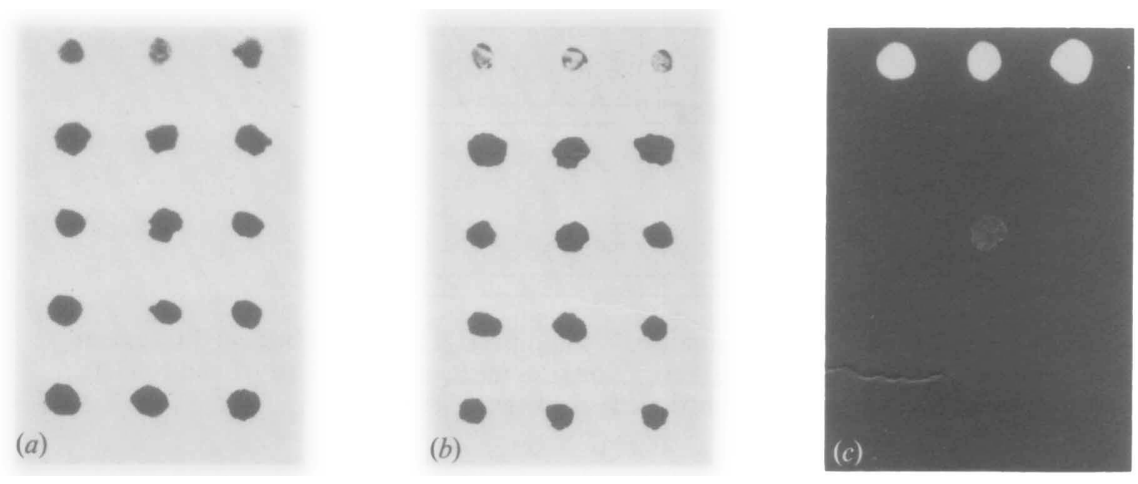

$\mathrm{NF} 3(\mathrm{pNH} 2)$

NF3(pNH213)

$\mathrm{NF} 3(\mathrm{pNH} 21)$

$8253(\mathrm{pNH} 2)$

8253(pNH21)

Fig. 3. Enhanced fluorescence in $R b$. sphaeroides. Colonies from the strains indicated were analysed for (a) aerobic growth, (b) photosynthetic growth, and (c) enhanced fluorescence (see Methods).

(a)

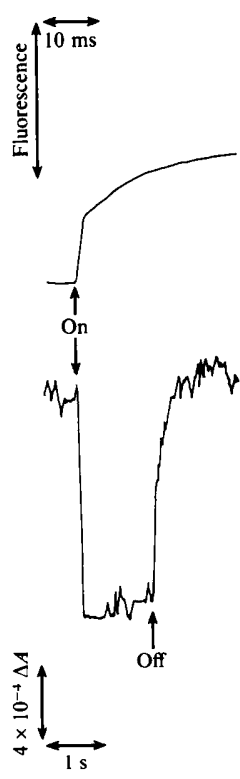

(b)

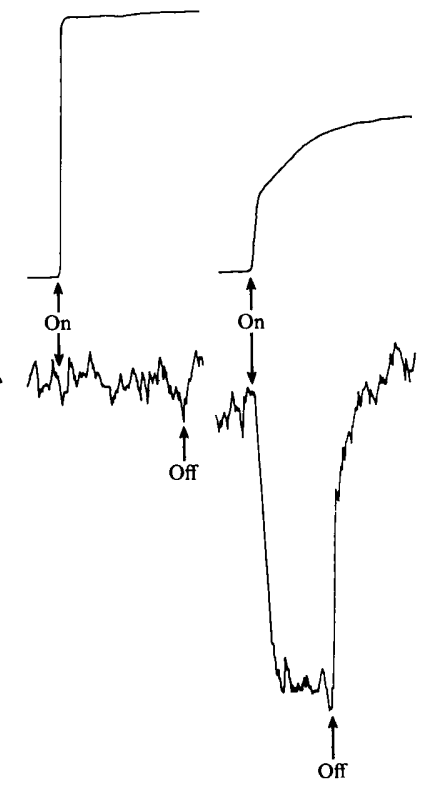

(c)

Fig. 4. Fluorescence properties (top traces) and reaction centre activity (bottom traces) in wild-type, mutant and recombinant strains of $R b$. sphaeroides: (a) wild-type, (b) mutant NF3, (c) NF3(pNH21). Membrane samples corresponding to the traces were all normalized with respect to the bacteriochlorophyll concentration as approximated by the absorbance at $850 \mathrm{~nm}$.

\section{Examination of the properties of mutant NF3 and transconjugant strains}

The loss and subsequent recovery of reaction centre function has measurable effects on the spectroscopic properties and electrophoretic profiles of membrane polypeptides. These properties were examined in order to confirm that both transfer and expression of puf genes had occurred. Colonies of NF3 showed the enhanced level of fluorescence noted by Youvan et al. 


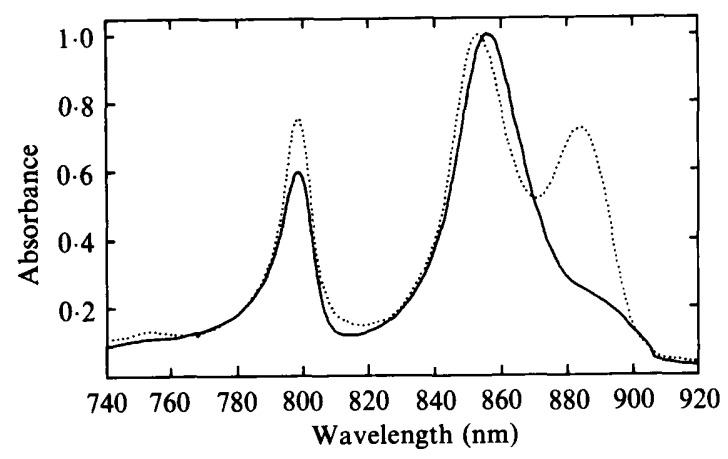

Fig. 5. Low-temperature absorption spectrum of membranes from mutant NF3 (-) and recombinant strain NF3(pNH21) (…). These spectra were recorded at $4 \mathrm{~K}$ in order to provide resolution between absorbance peaks at 850 and $875 \mathrm{~nm}$.

(1983) in their study of reaction-centre-less mutants of $R b$. capsulatus. This property arises from the absence of reaction centres which normally receive excitation energy from the lightharvesting system, and the consequent re-emission of this energy as fluorescence over and above the normal level. Control experiments, in which the vector $\mathrm{pNH} 2$ was introduced into NF3, and pNH 21 and pNH213 were introduced into the wild-type, showed no alteration of the properties of either strain (Fig. 3). pNH21 restored photosynthetic growth to NF3 and a normal degree of fluorescence.

This is shown in more detail in Fig. 4, in which the kinetics of the fluorescence rise are displayed together with the steady-state absorption signal which arises when the 'special pair' bacteriochlorophyll dimer within the reaction centre becomes photo-oxidized. The quantitative basis for the enhanced fluorescence of NF3 is explained here by the eventual level of fluorescence $\left(F_{\max }\right)$, which attains a value two- to threefold higher than in the wild-type. Moreover, the curved part of this rise in fluorescence, which corresponds to the eventual closing of reaction centre 'traps', is absent in NF3 and restored by transfer of pNH21. These results are similar to those obtained by reconstitution of detergent-solubilized reaction centre complexes into membranes from another mutant, PM8dp (Hunter et al., 1979).

The absorption spectrum at $4 \mathrm{~K}$ (Fig. 5) shows that the B875 (LH1) complex, the polypeptides of which are encoded by puf $A$ and $B$, is present in mutant NF3; this can be detected as an $875 \mathrm{~nm}$ shoulder on the main peak at $850 \mathrm{~nm}$ which arises from the major LH2 complex, B800850 . Interestingly, pNH21 enhances the relative amount of $\mathrm{B875}$ in addition to restoring reaction centres. Northern blots of RNA from mutant NF3 and the wild-type are compared in Fig. $6(a)$. In the wild-type, two transcripts of 2.6 and $0.5 \mathrm{~kb}$ are seen, in agreement with Zhu \& Kaplan (1985). The larger transcript encodes puf $A, B, L$ and $M$ genes for B875 and reaction centre polypeptides, whereas the smaller transcript is specific for B875. In mutant NF3 only the small species can be detected. SDS-PAGE confirms that reaction centre polypeptides are absent in the mutant and are restored in transconjugant strains (Fig. 6b). It is not possible to be more precise unless antibodies are used to establish whether or not the $\mathrm{H}$ subunit encoded by puhA (Donohue et al., 1986) is present.

In summary, the data in Figs 3-6 establish that mutant NF3 is capable of synthesizing a lightharvesting system consisting of $\mathrm{B} 800-850$ and $\mathrm{B} 875$ but not the reaction centre complex. The mutation is probably in the puf $L$ or $M$ genes and can be complemented by mobilization of the puf operon. 

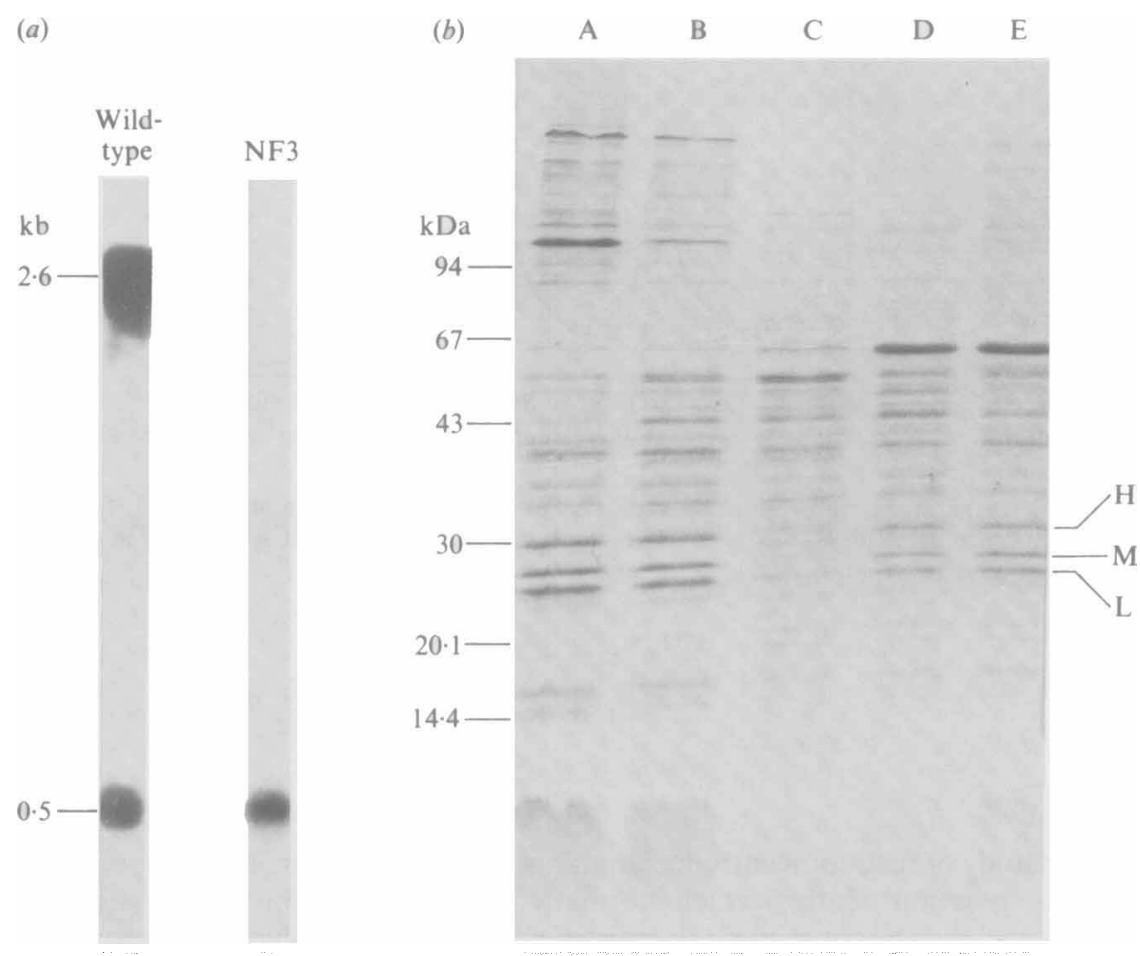

Fig. 6. (a) Northern blot of total RNA from mutant NF3 and the wild-type, showing transcripts of puf genes. The filter was probed with the $7.2 \mathrm{~kb} \mathrm{BamHI-HindIII}$ fragment of pJW1, which includes puf genes $A, B, L$ and $M$. (b) SDS-PAGE of membranes from mutant, wild-type and recombinant strains. The apparent molecular masses of the standards are indicated on the left, and the positions of the three reaction centre subunits $H, M$ and $L$ on the right. Tracks: $A$, wild-type grown under low aeration in the dark; B, wild-type grown photosynthetically; C, mutant NF3, low aeration in the dark; D, transconjugant strain NF3(pNH21), low aeration in the dark; E, transconjugant strain NF3(pNH21) grown photosynthetically.

\section{DISCUSSION}

In another study, the RSF1010-based vector pMA 81 was used to transfer $p u c A, B$ genes for the LH2 complex to mutant M21 (Ashby et al., 1987). Although the vector system studied here was largely that based on pNH2, and in turn on RSF1010, there is no particular advantage in using a broad-host-range system rather than one based upon the 'suicide' vector pSUP202 which does not replicate in $R b$. sphaeroides. If a recombination-deficient strain of $R b$. sphaeroides can be isolated or constructed (for example Sistrom et al., 1984), this would allow RSF1010 derivatives to fulfil their potential as shuttle vectors. The importance of such strains has also been pointed out by Weaver \& Tabita (1985). One advantage in cloning genes from a bank of $R b$. sphaeroides DNA in pSUP202 is that inserts can be examined further by localized transposon mutagenesis without the need for subcloning (Hunter, 1988). Thus bch genes isolated by complementation of mutants lacking bacteriochlorophyll (Hunter \& Coomber, 1988) can be analysed in the same vector by transposon Tn 5 mutagenesis (M. Chaudri, S. Coomber \& C. N. Hunter, unpublished results).

The high efficiency of using pRK2073 triparentally to mobilize vectors from $E$. coli DH5 is a useful system for routine cloning and transfer of $R b$. sphaeroides DNA. It avoids the use of $E$. coli strain $\mathrm{Sm} 10$, which is transformed with a relatively low efficiency. This method is particularly effective when combined with pSUP202, which has several useful cloning sites (Simon et al., 1983). 
The authors gratefully acknowledge financial support from the Science and Engineering Research Council of Great Britain, and helpful advice from Drs P. Bennett and J. Grinsted. C. N. H. is also grateful to John Olsen for technical assistance, to Rob van Dorssen for performing low-temperature absorbance spectroscopy, and to Shirley Coomber and Dr M. J. McPherson for developing the method for mRNA extraction.

\section{REFERENCES}

Ashby, M. K., CoOmber, S. A. \& Hunter, C. N. (1987). Cloning, nucleotide sequence and transfer of genes for the B800-850 light harvesting complex of Rhodobacter sphaeroides. FEBS Letters 213, 245-248. CoOmber, S. A., Ashby, M. K. \& Hunter, C. N. (1987). Cloning and oxygen regulated expression of genes for the bacteriochlorophyll biosynthetic pathway in Rhodopseudomonas sphaeroides. In Progress in Photosynthesis Research, vol. 4, pp. 737-740. Edited by J. Biggins. Dordrecht: Martinus Nijhoff.

Deisenhofer, J., EPP, O., Miki, K., Huber, R. \& MiCHEL, H. (1985). Structure of the protein subunits in the photosynthetic reaction centre of Rhodopseudomonas viridis at $3 \AA$ resolution. Nature, London 318, 618-624.

Donohue, T. J., McEwan, A. G. \& Kaplan, S. (1986). Cloning and expression of the Rhodobacter sphaeroides reaction centre $\mathbf{H}$ gene. Journal of Bacteriology 168, 962-972.

Franklin, F. C. H. (1985). Broad host range cloning vectors for Gram negative bacteria. In DNA Cloning, vol. I, A Practical Approach, pp. 165-184. Edited by D. M. Glover. Oxford: IRL Press.

HANAHAN, D. (1985). Techniques of transformation in E. coli. In DNA Cloning, vol. 1, pp. 109-135. Edited by D. M. Glover. Oxford: IRL Press.

HUNTER, C. N. (1988). Transposon Tn5 mutagenesis of genes encoding reaction centre and light-harvesting LH1 polypeptides of Rhodobacter sphaeroides. Journal of General Microbiology 134, 1481-1489.

HUNTER, C. N. \& COOMBER, S. A. (1988). Cloning and oxygen-regulated expression of the bacteriochlorophyll biosynthesis genes bch $E, B, A$ and $C$ of Rhodobacter sphaeroides. Journal of General Microbiology 134, 1491-1497.

HunTER, C. N., van Grondelle, R., Holmes, N. G. \& JONES, O. T. G. (1979). The reconstitution of energy transfer in membranes from a bacteriochlorophyllless mutant of Rhodopseudomonas sphaeroides by addition of light harvesting and reaction centre pigment protein complexes. Biochimica et biophysica acta 548, 458-470.

KRAMER, H. J. M. \& Amesz, J. (1982). Anisotropy of the emission and absorption bands of spinach chloroplasts measured by fluorescence polarization and polarized excitation spectra at low temperature. Biochimica et biophysica acta 682, 201-207.

LAEMMLI, U. K. (1970). Cleavage of structural proteins during the assembly of the head of bacteriophage T4. Nature, London 227, 680-685.

Leong, S. A., Ditta, G. S. \& Helinski, D. R. (1982). Heme biosynthesis in Rhizobium. Identification of a cloned gene coding for $\delta$-aminolevulinic acid synthetase from Rhizobium meliloti. Journal of Biological Chemistry 257, 8724-8730.

Maniatis, T., Fritsch, E. F. \& Sambrook, J. (1982). Molecular Cloning. A Laboratory Manual. Cold Spring Harbor, NY: Cold Spring Harbor Laboratory.
Miller, L. \& KaPlan, S. (1978). Plasmid transfer and expression in Rhodopseudomonas sphaeroides. Archives of Biochemistry and Biophysics 187, 229-234.

Simon, R., Priefer, U. \& PüHLER, A. (1983). A broad host range mobilization system for in vivo genetic engineering : transposon mutagenesis in Gram negative bacteria. Biotechnology 1, 784-791.

SISTROM, W. R. (1977). Transfer of chromosomal genes mediated by plasmid R68.45 in Rhodopseudomonas sphaeroides. Journal of Bacteriology 131, 526-532.

Sistrom, W. R. \& Clayton, R. K. (1964). Studies on a mutant of Rhodopseudomonas sphaeroides unable to grow photosynthetically. Biochimica et biophysica acta 88, 61-73.

Sistrom, W. R., Macaluso, A. \& Pledger, R. (1984). Mutants of Rhodopseudomonas sphaeroides useful in genetic analysis. Archives of Microbiology 138, 161165.

TAYlor, D. P., Cohen, S. N., Clark, W. G. \& Marrs, B. L. (1983). Alignment of genetic and restriction maps of the photosynthesis region of the Rhodopseudomonas capsulata chromosome by a conjugationmediated marker rescue technique. Journal of Bacteriology 154, 580-590.

ThOMAS, P. (1983). Hybridization of denatured RNA transferred or dotted to nitrocellose paper. Methods in Enzymology 100, 255-266.

Vos, M., VAN Grondelle, R., VAN DER KoOIJ, F. W., VAN DER Poll, D., Amesz, J. \& DuYsens, L. N. M. (1986). Singlet-singlet annihilation at low temperatures in the antenna of purple bacteria. Biochimica et biophysica acta 850, 501-512.

Weaver, K. E. \& Tabita, F. R. (1985). Complementation of a Rhodopseudomonas sphaeroides ribulose bisphosphate carboxylase-oxygenase regulatory mutant from a genomic library. Journal of Bacteriology 164, 147-154.

Williams, J. C., Steiner, L. A., Ogden, R. C., Simon, M. I. \& FeHER, G. (1983). Primary structure of the M subunit of the reaction center from Rhodopseudomonas sphaeroides. Proceedings of the National Academy of Sciences of the United States of America 80, 6505-6509.

Williams, J. C., Steiner, L. A., Feher, G. \& Simon, M. I. (1984). Primary structure of the L subunit of the reaction center of Rhodopseudomonas sphaeroides. Proceedings of the National Academy of Sciences of the United States of America 81, 7303-7308.

YeN, H. C., Hu, N. T. \& Marrs, B. L. (1979). Characterisation of the gene transfer agent made by an overproducer mutant of Rhodopseudomonas capsulata. Journal of Molecular Biology 131, 157-168.

Youvan, D. C., Hearst, J. E. \& MarRs, B. L. (1983). Isolation and characterisation of enhanced fluorescence mutants of Rhodopseudomonas capsulata. Journal of Bacteriology 154, 748-755.

ZhU, Y. S. \& KaPLAN, S. (1985). Effects of light, oxygen, and substrates on steady-state levels of mRNA coding for ribulose-1,5-bisphosphate car- 
boxylase and light harvesting and reaction center polypeptides in Rhodopseudomonas sphaeroides. Journal of Bacteriology 162, 925-932.

ZHU, Y. S., KILEY, P. J., DONOHUE, T. J. \& KaPLAN, S. (1986). Origin of the mRNA stoichiometry of the puf operon in Rhodobacter sphaeroides. Journal of Biological Chemistry 261, 10366-10374.
Zinchenko, V. V., BabyKin, M. M. \& Shestakov, S. V. (1984). Mobilization of non-conjugative plasmids into Rhodopseudomonas sphaeroides. Journal of General Microbiology 130, 1587-1590. 